Erratum

\title{
Erratum: Kim, B.-R., et al. A Study on Flow Characteristics and Flow Uniformity for the Efficient Design of a Flow Frame in a Redox Flow Battery. Appl. Sci. 2020, 10, 929
}

\section{Applied Sciences Editorial Office}

\section{check for}

updates

Citation: Erratum: Kim, B.-R., et al. A Study on Flow Characteristics and Flow Uniformity for the Efficient Design of a Flow Frame in a Redox Flow Battery. Appl. Sci. 2020, 10, 929. Appl. Sci. 2021, 11, 978. https://doi.org/10.3390/app11030978

Received: 31 December 2020

Accepted: 8 January 2021

Published: 22 January 2021

Publisher's Note: MDPI stays neutral with regard to jurisdictional claims in published maps and institutional affiliations.

Copyright: (C) 2021 by the author. Licensee MDPI, Basel, Switzerland. This article is an open access article distributed under the terms and conditions of the Creative Commons Attribution (CC BY) license (https:// creativecommons.org/licenses/by/ $4.0 /)$.
MDPI AG, St. Alban-Anlage 66, 4052 Basel, Switzerland

We wish to make the following corrections to the published paper [1]. The authorship and Author Contributions are incorrect. They should be as follows:

Bo-Ra Kim ${ }^{1}$, Deok-Young Sohn ${ }^{1}$, Yun-Ho Choi ${ }^{1, *}$ and Yong-Hee Lee ${ }^{2}$

Author Contributions: Conceptualization, B.-R.K., Y.-H.C. and Y.-H.L.; methodology, B.-R.K. and D.-Y.S.; software, B.-R.K.; formal analysis, B.-R.K. and D.-Y.S.; validation (experiment), B.-R.K., and Y.-H.L.; writing. B.-R.K., Y.-H.C.; supervision, Y.-H.C.; project administration, D.-Y.S. and Y.-H.C. All authors have read and agreed to the published version of the manuscript.

Conflicts of Interest: The authors declare no conflict of interest.

\section{Reference}

1. Park, J.-Y.; Kim, B.-R.; Sohn, D.-Y.; Choi, Y.-H.; Lee, Y.-H. A Study on Flow Characteristics and Flow Uniformity for the Efficient Design of a Flow Frame in a Redox Flow Battery. Appl. Sci. 2020, 10, 929. [CrossRef] 